\title{
Effect of Degraded Ecosystem on Fish Biodiversity in the Old Brahmaputra River, Bangladesh and Its Conservation Measures
}

\author{
Sania Afrose ${ }^{1}$, Nesar Ahmed ${ }^{2}$ \\ ${ }^{1}$ Master in Marine and Lacustrine Science and Management, Vrije Universiteit Brussel, Belgium \\ ${ }^{2}$ Faculty of Fisheries, Bangladesh Agricultural University (BAU), Bangladesh
}

\begin{abstract}
The study was conducted about the ecosystem-based approach on fisheries management of the Old Brahmaputra River in Mymensingh region, Bangladesh. The primary area for the study was in the Old Brahmaputra River adjacent to the Bangladesh Agricultural University, Mymensingh. This research focused on the identification of proper management strategies for the conservation of fish biodiversity. There are degraded ecosystems and declining biodiversity have found during the study. According to the survey, fishing pressure and overexploitation were responsible for almost $42 \%$, and water pollution caused about $35 \%$ loss of fish biodiversity. Around $17 \%$ and $10 \%$ loss of fish biodiversity were caused by Change of river course, and the habitat degradation respectively within the study area. These have been created a great impact on river ecology and surrounding river conditions. As a result, the water quality is deteriorating day by day and the availability of fish species and other aquatic biodiversity is decreasing gradually. During the survey, 19 species were also found at a risk of being endangered. This study identified possible ways to achieve a rich fish biodiversity in the Old Brahmaputra River with social, economic and environmental aspects. The specific recommendations are included community-based fisheries management, establishment of sanctuary, control of pollution, maintenance of fishing gears and the implementation of the fish act for the conservation of fish biodiversity of the Old Brahmaputra River.
\end{abstract}

Keywords: Conservation measures, Fish biodiversity, Old Brahmaputra River, Riverine ecosystem

\section{Introduction}

Fisheries make crucial contributions to the world's wellbeing and prosperity. In the last five decades, world fish food supply has outpaced global population growth, and today fish constitutes an important source of nutritious food and animal protein for much of the world's population [1]. Fish and fisheries are the indispensable part of life and livelihood of the people of Bangladesh too since immemorial time. It is an element of the country's cultural heritage [2]. Total global capture production in inland waters has increased dramatically since the mid-2000s. Total production amounted to 11.2 million tonnes in 2010, an increase of 30\% since 2004 [1].Bangladesh is one of the world's leading inland fisheries producer with an annual production of fish was 1.05 million metric tonnes which constituted 34.45\% of total catch in 2011 [2]. The main factor that threatens marine fish biodiversity globally is fishing $[3,4]$. For example, worldwide over 40 local populations of marine fishes have gone extinct as a result of overexploitation [3]. These local losses represent an erosion of global biodiversity. Moreover, stresses due to other factors such as climate change, habitat loss, invasive species, eutrophication, and pollution can accentuate fishing-induced declines and inhibit or prevent recoveries [4].

Biodiversity and its conservation are regarded as one of the major issues of enabling sustainable use of natural resources and is essential for the Old Brahmaputra River. Conservation helps fish production to be more sustainable while at the same time maintains diversity. Conserving diversity also improves the likelihood of maintaining minimal viable populations of rare and late-successional species. Maintaining biodiversity is important because it is not always possible to identify which individual species are critical to aquatic ecosystems sustainability. Many fish species may provide genetic material and may serve as ecological indicators. Diversity reduces disease problems and encourages recovery from disturbance. Aquatic conservation strategies support sustainable development by protecting biological resources in ways that will preserve habitats and ecosystems. In order for biodiversity conservation to be effective, management measures must be broad-based [5]. The effects of changes in biodiversity on ecosystem functioning are becoming evident, although there is uncertainty, many fishery-induced changes in species and size composition of fish communities are now well documented by Garcia et al. [4]. What has recently become clearer is that these changes affect the structure and functioning of marine ecosystems, including the biomass of species at lower tropic levels [6]. Fisheries managers and policy makers must, therefore, take a precautionary approach in their management of fish diversity.

Islam and Ahmed [7] implied that mass destruction of valuable aquatic organisms by shrimp seed collectors is a serious threat to biodiversity and coastal ecosystem integrity. Kalpana and Seth [8] studied on the conservation of biodiversity and reported that the factors adversely affecting aquatic communities are 
encroachment, siltation, weed infestation and pollution. They also studied on the concept, significance, and conservation of aquatic biodiversity and reported that threats to aquatic biodiversity are changes in land use; construction of man-made lakes; aquatic pollution; overexploitation of organisms; introduction of alien species; global warming and sea level rise; and the secondary effect of extinction. Cowx et al. [9] studied on the sustainability of the fishery reported that considerable illegal fishing, using banned gears and small-meshed nets was prevalent and considered to be detrimental to the sustainability of the fishery. Odada et al. [10] studied on the environmental assessment of the East African Rift Valley Lakes and reported that loss of biodiversity occurs due to unsustainable exploitation of fisheries and other living resources are caused by over-fishing, destructive fishing practices, and introduction of non-native species that affect the composition of the native communities, resulting sometimes in the collapse of certain species and dominance by resilient ones.

Raj [11] reported freshwater fish biodiversity and conservation measures in India. He suggested taking necessary actions like the establishment of the sanctuary, determination of the environmental requirements of the species etc. Jenkins and Williamson [5] studied on how we should conserve biodiversity and emphasis are given on species-based conservation (threatened species, ecologically important species, species useful to humans, species with non-use values), area-based conservation, and ecosystem approaches. The major constraints on the effectiveness of ongoing efforts to conserve existing biological diversity are enumerated and specific measures for increasing the effectiveness of conservation efforts are provided. Edward and Plaganyi [12] spatially defined restrictions on fishing activities are considered to be important for biodiversity conservation in marine ecosystems. However, it is uncertain whether such restrictions also benefit wider populations of exploited fish species, in terms of a reduced risk of overexploitation. This investigation explores the benefits of protecting older fish and how spatial management can be used to adjust the age structure and improve the sustainability of the catch mainly its productivity.

Kabir et al. [13] about 54 freshwater species are critically or somewhat endangered in Bangladesh. Among them 14 species are listed as critically endangered; 27 as endangered and 14 as vulnerable. Overfishing, rapid extraction of fish seed and brood stock, destructive and unregulated fishing practices, pollution, the introduction of exotic species, loss of aquatic habitat due to siltation, dam construction, and other anthropogenic activities have been the major causes of fish species loss. Human activities are causing species to disappear at an alarming rate. Aquatic species are at a higher risk of extinction than mammals and birds. Losses of this magnitude impact the entire ecosystem, depriving valuable resources used to provide food, medicines, and industrial materials to human beings. Runoff from agricultural and urban areas, the invasion of exotic species, and the creation of dams and water diversion have been identified as the greatest challenges to freshwater environments [14]. William et al. [15] mentioned that principal causes behind the recent increase in the loss of fish biodiversity in Bangladesh include habitat alternation, fragmentation, and simplification. Physical habitat is altered by channelization, construction of embankments and diversions, siltation, and degradation of wetlands. A more broad-based approach to fisheries management and for greater recognition of the importance of other non-commercial taxa in supporting the ecosystems that maintain fisheries. Appreciation for the role of all taxa within the food webs upon which the fisheries are based must be integrated into management thinking for those fisheries. Managers should adopt the precautionary approach and manage fisheries to maintain species diversity $[16,17])$.

An ecosystem is a community of living organisms (plants, animals, and microbes) in conjunction with the non-living components of their environment (things like air, water and mineral soil), interacting as a system. These components are regarded as linked together through nutrient cycles and energy flows. As ecosystems are defined by the network of interactions among organisms, and between organisms and their environment, they can come in any size but usually encompass specific, limited spaces although it is sometimes said that the entire planet is an ecosystem. The ecosystem of a river is the river viewed as a system operating in its natural environment, and includes biotic (living) interactions amongst plants, animals, and micro-organisms, as well as abiotic (non-living) physical and chemical interactions. In the Old Brahmaputra River, abiotic factors include the water flow, light, temperature, concentration of nutrients, oxygen, carbon dioxide, ammonia, dissolved salt, PH and substrates like fine particles, autumn shed leaves, submerged wood and moss. On the other hand, biotic organisms include different types of fish, other aquatic animals like insects, crabs, snails, oysters, mussels, aquatic birds, dolphins, frogs and snakes. This also includes different types of aquatic plants which provide oxygen for aquatic animals in the river. In addition, another important living factor is micro-organisms which help in decomposition and make the nutrient cycle continuous. The main objectives of this study were to identify possible threats to ecosystem and biodiversity of the river and to recommend ecosystem-based fisheries management. 


\section{Selection of the Study Area}

\section{Materials And Methods}

Selecting of the study area for the research is an important step. The purpose would, therefore, be better served in an area where there is a good source of recreational fisheries. With this view, the Old Brahmaputra River of Mymensingh region was selected for the present study area. The primary area for the study was in the Old Brahmaputra River adjacent to the Bangladesh Agricultural University, Mymensingh, from Railway Bridge (Kalibari Ghat-Latitude 24.754239 $\mathrm{N}$ and Longitude $90.417747^{\circ} \mathrm{E}$ ) to the end of the university campus (Latitude $24.719159^{\circ} \mathrm{N}$ and Longitude $90.447431^{\circ} \mathrm{E}$ ). The Old Brahmaputra River is famous for its rich reserve of aquatic life. A large number of rural people live in the east of the riverbank, whose livelihoods culture and daily activities are related and adapted to its aquatic environment.

\section{Data collection methods}

The credibility of the results of a scientific research depends largely on the appropriate methodology used in research. Data were collected from target groups by questionnaire interviews, Participatory Rapid Appraisal (PRA) tool such as Focus Group Discussion (FGD) and cross-check interviews with key informants. The sample size was taken about $30 \%$ of individual interviews, $50 \%$ of FGD and $20 \%$ of the cross-check interviews with the key informants of the study area. Samples were selected randomly.

\section{Design and formulation of questionnaire}

To collect data, preparation of questionnaire is, of course, a crucial need for survey method. Before preparing the questionnaire, a draft questionnaire was developed and then tested in the study area keeping in view the objectives of the study. The questionnaire was then changed, modified and rearranged according to the experience gather in the testing. The final questionnaire was then developed in a logical sequence so that the fishers could answer systematically.

\section{Questionnaire interviews}

A collection of accurate and reliable data and another necessary information from the field is not an easy work. It must be done properly since the success of the questionnaire interviews depends on the reliability of data. Data were collected from primary source by researcher herself as questionnaire interviews with fishers (Plate 1). Before going to make an actual interview, a brief introduction about the objectives of the study was given to each of the selected groups and assured them that all information would be kept confidential. At the time of interview each question was explained clearly and asked systematically as for their sound understanding. Interview schedules were prepared for collection of relevant data in accordance with the objectives of the study. Both open and closed form of questions was used to collect information. Simple and direct questions were included in the schedule to ascertain the opinion of the target groups. Questions related to socioeconomic conditions of target groups such as age, education, family income, family size, fishing duration, available fish species and other relevant aspects were included in the questionnaire

\section{Participatory Rapid Appraisal}

Participatory Rapid Appraisal (PRA) is a group of methods to collect information from target groups in a participatory fashion. The participation of target groups provides an opportunity for cross checking individuals' opinions as well as allowing the community to discuss the issues that they feel important, rather than responding to the questionnaire. The advantages of PRA over other methods are that the information collected is likely to be more accurate. For the present study, PRA tools such as FGD was conducted with fishers, boatmen, anglers and river bank community. In this study, FGD was used to get an overview of particular issues such as existing fishing systems, socio-economic condition of fishers, the ecosystem of river, present condition of river, causes of the reduction of fish availability etc. A total of 3 FGD sessions were conducted in the river area where each group size of FGD was 6 to 12 fishers (Plate 2). FGD sessions were held at fishers houses, under the big trees where there was spontaneous gathering.

\section{Cross-check interviews with key informants}

Having interviews with respondents, it is necessary to check the informants for verifying the collected data. If there were such items, which had been contradictory, then information was collected from key informants. Cross-check interviews were conducted with key informants such as advanced fishers, researcher, government fisheries officer, school teacher and NGO workers. Key informants interviews were conducted individually. Key informants were interviewed individually and group wise. Group interviews conducted with care since some individuals dominated the discussion. 


\section{Results And Discussion}

It is very essential to know the biodiversity and the ecosystem of the Old Brahmaputra River to get a complete picture of the status of the river. The study was conducted in the Old Brahmaputra River adjacent to the Bangladesh Agricultural University, Mymensingh. The survey was done through questionnaire interviews, focus group discussions and cross-check interviews with key informants. Both qualitative and quantitative analysis were used to analyze the survey data.

Survey shows that the group of catfish contained the highest amount of species variety and the second highest species variety was found in the group of barb. Among the total 39 species of fishes there are $10.26 \%$ of Indian major carp, $2.56 \%$ of minor carp, $12.82 \%$ of barb, $7.69 \%$ of snakehead, $5.13 \%$ of loach, $2.56 \%$ of molacarplet, $17.95 \%$ of catfish, $2.56 \%$ of mullet, $2.56 \%$ of gourami, $5.13 \%$ of spiny eel, $5.13 \%$ of climbing perch, $2.56 \%$ of tank goby, $7.69 \%$ of minnow, $5.13 \%$ of small prawn, $2.56 \%$ of freshwater garfish, $5.13 \%$ of perchlet and $2.56 \%$ of river shad (Table 1). A survey with the fishers showed even five years ago about 60 to 65 species were found in the Old Brahmaputra River and now the number has been declined at 39 species. The details catch composition and the fishing practice in the Old Brahmaputra River will be published elsewhere.

Table 1 Variety of fish species caught under different groups

\begin{tabular}{|l|l|l|l|}
\hline SI. No. & Group of fish & $\begin{array}{l}\text { Number of species } \\
\text { caught under the group }\end{array}$ & $\begin{array}{l}\text { Percentage (\%) of } \\
\text { species caught }\end{array}$ \\
\hline 1 & Indian major carp & 4 & 10.26 \\
\hline 2 & Minor carp & 1 & 2.56 \\
\hline 3 & Barb & 5 & 12.82 \\
\hline 4 & Snakehead & 3 & 7.69 \\
\hline 5 & Loach & 2 & 5.13 \\
\hline 6 & Molacraplet & 1 & 2.56 \\
\hline 7 & Catfish & 7 & 17.95 \\
\hline 8 & Mullet & 1 & 2.56 \\
\hline 9 & Gourami & 1 & 2.56 \\
\hline 10 & Spiny eel & 2 & 5.13 \\
\hline 11 & Climbing perch & 2 & 5.13 \\
\hline 12 & Tank goby & 1 & 2.56 \\
\hline 13 & Minnows & 3 & 7.69 \\
\hline 14 & Small Prawn & 2 & 5.13 \\
\hline 15 & Freshwater garfish & 1 & 2.56 \\
\hline 16 & Perchlet & 2 & 5.13 \\
\hline 17 & River shad & 1 & 2.56 \\
\hline
\end{tabular}

Besides the variety of fish, there are also so many other aquatic animals are found in the Old Brahmaputra River. The questionnaire interviews with the fishers show there are plenty of other animals like aquatic birds, crabs, snails, mussels, turtles, snakes, dolphins and frogs. Fishers mentioned two species of aquatic birds, one species of crab, three species of mussel, one species of snail, one species of turtle, one species of snake, one species of dolphin and one species of frog (Table 2). They also mentioned that the turtle and dolphin are hardly seen in the river nowadays.

Table 2 Other Aquatic Animals those are found in the Old Brahmaputra River

\begin{tabular}{|l|l|l|l|}
\hline \multirow{2}{*}{ Sl. No. } & Species & \multicolumn{3}{|c|}{} \\
\cline { 2 - 4 } & Group Name & Local Name & Scientific Name \\
\hline 1 & Aquatic bird & $\begin{array}{l}\text { Maachranga } \\
\text { Bok }\end{array}$ & $\begin{array}{l}\text { Alcedo atthis } \\
\text { Grus grus }\end{array}$ \\
\hline 2 & Crab & Mud crab & Scylla serrata \\
\hline 3 & Snail & Apple shamuk & Pila globosa \\
\hline 4 & Mussel & Jhinuk & $\begin{array}{l}\text { Lamellidens marginalis } \\
\text { L. jenkinsianus }\end{array}$ \\
\hline 5 & Turtle & Kossop & Melanochelys tricarinata \\
\hline 6 & Snake (aquatic) & Guisaap & Varanus bengalensis \\
\hline 7 & Dolphin & Shushuk & Platanista gangetica \\
\hline 8 & Frog & Kuno bang & Bufo melanostictus \\
\hline
\end{tabular}

\section{Threats to Fisheries Biodiversity}

Biodiversity is the degree of variation of life forms within a given species, ecosystem, biome, or an entire planet. Biodiversity is a measure of the health of ecosystems. Biodiversity is in part a function of climate. In terrestrial habitats, tropical regions are typically rich whereas Polar Regions support fewer species. Freshwater ecosystems may well be the most endangered ecosystems in the world. Declines in biodiversity are far greater in freshwater than in the most affected terrestrial ecosystems. The threats to fisheries biodiversity can be grouped under four interacting categories: overexploitation, water pollution, change of river course, destruction or degradation of habitat. 
Due to the increasing population fishing pressure and overexploitation is increasing day by day. The river course is changed because of the dam, bridges which are the main causes of drought, flood. The combined and interacting influences of these four major threat categories have resulted in population declines and range reduction of the Old Brahmaputra River biodiversity. During questionnaire survey with fishers, most of them (73\%) reported that the many fish species once abundant in the Old Brahmaputra River, but now become rare (Table 3). From the survey 19 species have been found at a risk of being endangered. Among those fishes all are ecologically important but a few fishes like mohashol, khorola, baghayre, chitol, foli, pabda and kanipabda are as well as commercially important. But they become completely extinct according to survey data.

Table 3 Endangered fish species in the Old Brahmaputra River

\begin{tabular}{|c|c|c|c|c|}
\hline \multirow{2}{*}{$\begin{array}{l}\text { Sl. } \\
\text { No. }\end{array}$} & \multicolumn{2}{|l|}{ Species Name } & \multirow{2}{*}{$\begin{array}{l}\text { Ecologically } \\
\text { Important Species }\end{array}$} & \multirow{2}{*}{$\begin{array}{l}\text { Commercially } \\
\text { Important Species }\end{array}$} \\
\hline & Local Name & Scientific Name & & \\
\hline \multicolumn{5}{|c|}{ Critically endangered species } \\
\hline 1 & Mohashol & Tor tor & $\sqrt{ }$ & $\sqrt{ }$ \\
\hline 2 & Khorola & Rhinomugil corsula & $\sqrt{ }$ & $\sqrt{ }$ \\
\hline 3 & Lal kholisha & Colisa labius & $\sqrt{ }$ & \\
\hline 4 & Chitol & Chitala chitala & $\sqrt{ }$ & $\sqrt{ }$ \\
\hline 5 & Foli & Notopterus notopterus & $\sqrt{ }$ & $\sqrt{ }$ \\
\hline 6 & Pathorchata & Barilius tileo & $\sqrt{ }$ & \\
\hline 7 & Kanipabda & Ompok bimaculatus & $\sqrt{ }$ & \\
\hline \multicolumn{5}{|c|}{ Endangered species } \\
\hline 8 & Bacha & Eutropiichthys vacha & $\sqrt{ }$ & \\
\hline 9 & Baghayre & Bagarius bagarius & $\sqrt{ }$ & $\sqrt{ }$ \\
\hline 10 & Gajar & Channa marulius & $\sqrt{ }$ & $\sqrt{ }$ \\
\hline 11 & Pabda & Ompok pabda & $\sqrt{ }$ & $\sqrt{ }$ \\
\hline 12 & Bashpata & Ailia coilia & $\sqrt{ }$ & \\
\hline 13 & Gonia & Labeo gonia & $\sqrt{ }$ & \\
\hline 14 & Gutum & Lepidocephalus guntea & $\sqrt{ }$ & \\
\hline \multicolumn{5}{|c|}{ Vulnerable } \\
\hline 15 & Dhela & Osteobrama cotio & $\sqrt{ }$ & \\
\hline 16 & cheka & Chela laubuca & $\sqrt{ }$ & \\
\hline 17 & Bata & Labeo bata & $\sqrt{ }$ & \\
\hline 18 & Bou Rani & Botia dorio & $\sqrt{ }$ & \\
\hline 19 & Kajoli & Ailichthys punctata & $\sqrt{ }$ & \\
\hline
\end{tabular}

According to the survey, it was also found that the overexploitation of fishes was about $42 \%$ responsible for the loss of fish biodiversity in the Old Brahmaputra River and water pollution caused 35\% loss of biodiversity. Henceforth, river course change resulted in $17 \%$ of loss and habitat degradation caused $10 \%$ of biodiversity loss of the river (Table 4 ).

Table 4 Threats to the Fisheries Biodiversity in the Old Brahmaputra River

\begin{tabular}{|l|l|}
\hline Threats & Loss of Fisheries Biodiversity (\%) \\
\hline Fishing pressure and Overexploitation & 42 \\
\hline Water pollution & 35 \\
\hline Change of river course & 17 \\
\hline Habitat degradation & 10 \\
\hline
\end{tabular}

\section{Threats to ecosystem}

The ecosystem of the Old Brahmaputra River is very important to know as it affects the biodiversity of the river. If the ecosystem is good enough, biodiversity remains maintained and balanced. But the biodiversity of the river degrades with the loss of ecosystem. During questionnaire survey with fishers, most of them reported that the ecosystem of the Old Brahmaputra River is declining day by day. The most common reason identified b discussion with fishers for declining of the ecosystem were the destruction of the river basin, water quality deterioration, pollution, sedimentation and also the loss of biodiversity, declining of fish species availability. Again, the ecology of the Old Brahmaputra River is under great threat due to fishing pressure and over fishing i.e. indiscriminate fishing, pollution and siltation, urbanization and human encroachment i.e. transport, goods carrying and recreational activities i.e. mechanized boat, tourisms, and journey by boat. These have been created a great impact on river ecosystem.

\section{Conservation Measures}

During the survey with the fishers it was found that a lot of fishes are critically endangered and among them, some have already become extinct. So, it is high time to take necessary steps to conserve the biodiversity of the river. It has become essential to conserve the biodiversity to maintain a healthy environment as well as the ecosystem. With the consultation with fishers, some measures have been found. The community based fisheries 
management (CBFM) approach may play a vital role in the conservation management plan. In any water body CBFM is meant to pursue a management of development activities in the water resources that is based on a people-oriented concept and holistic approach. This approach is applied in order to get results better than those of government dominated management. CBFM seeks to develop and implement new practices of sustainable fisheries management that are responsible for the scale of communities, their fisheries, and their social and economic structures and dynamics. CBFM is that kind of management where a community or most of the people of a community or the actual fishers of a community of the adjacent area of a water body are engaged for jalmahal activities. CBFM is people-centered and community focused and the government may play a minor role in CBFM. It is a strategy undertaken through the active participation of an organized community. From the present study, it can be said that CBFM can be an ecological model or conceptual framework for sustainable fisheries management. Its activities cover the management of fisheries resources, fishing effort, and fishing grounds. Management covers not only conservation of fisheries resources such as setting catch limits but also the propagation of fisheries resources through ranching. Based on this goal, CBFM project can be launched as a better project for ecosystem-based fisheries management. Along with the CBFM, conservation can be employed by some other measures such as, fishing gear maintenance and pollution control by enforcing certain rules and regulation and by developing sanctuary in the study area to ensure sustainable fishing community without any disturbance.

\section{Conclusion}

Freshwater biodiversity and freshwater ecosystems are seriously jeopardized by human activities in monsoonal Asia. This is undoubtedly a consequence of the same large and growing human populations that are forcing the governments in the region to emphasize economic development above everything else. This does not necessarily reflect an absence of legislative frameworks to deal with at least some of the threats to biodiversity. China, for example, has as many environmental laws and policies as some western countries, but they are difficult to enforce and administer because of the many government commissions, departments, and ministries responsible for environmental matters. From the present study, the threats to fisheries biodiversity were grouped under four interacting categories: overexploitation, water pollution, change of river course, destruction or degradation of habitat. It was found through the survey that Overexploitation was the highest threat to the fisheries biodiversity of the Old Brahmaputra River with $42 \%$ loss and the lowest threat was the change of river course with $10 \%$ loss of fisheries biodiversity. Water pollution and habitat degradation caused about $35 \%$ and $17 \%$ loss of fisheries biodiversity of the Old Brahmaputra River respectively.

According to fishers from the survey, it can be applied in three ways which enforce the fishing laws; protection, preservation, and habitat improvement. The purpose of any fishery regulation from a strict conservation point of view is to provide a more bountiful harvest of fish either volume or net volume. In this study, it was observed that fishers have no training from any institution. If they got training from any institution, they will aware for protecting their own resources. Because of their unconsciousness they often break the rules and regulations such as the use of illegal fishing gear like current jal, catch of undersize and brood fish. So, with the discussion with fishers it has found that the implementation of rules and regulation should be strict by Government and make the fishers aware of sustainable yield and conserving ecosystem. Fishers suggest community-based fisheries management can be an ecological model or conceptual framework for sustainable fisheries biodiversity management. Its activities cover the management of fisheries resources, fishing effort, and fishing grounds. Management covers not only conservation of fisheries resources such as setting catch limits but also the propagation of fisheries resources through ranching. There is an urgent need to synthesize existing knowledge on this subject within a management/policy environment.

\section{References}

[1]. FAO, Fisheries and Aquaculture Report, Workshop on Fishery Stock Indicators and Stock Status, Tehran, Iran. Food and Agriculture Organization of the United Nations (FAO). Rome, Italy, 2012, 46

[2]. Department of Fisheries (DoF), Annual Report, Ministry of Fisheries and Livestock. The Government of Peoples Republic of Bangladesh, 12(4), 2012 319-328.

[3]. N. K. Dulvy, Y. Sadovy, and J. D. Reynolds, Extinction vulnerability in marine populations, Fish and fisheries, 4(1), $2003,25-64$.

[4]. S. Garcia, J. Boucher, P. Cury, O. Th'ebaud, M. Andriantsoa, A. Astudillo, M. Ba, D. McDonald,B. MacKenzie, and J. Rice, Workshop 10, Paris Conference: Biodiversity, Science and Governance, Ministry of Foreign Affairs, Government of France, Paris, France January 24-28, 2005.

[5]. M. Jenkins, and Williamson, D., Effectiveness of biodiversity conservation. In Biodiversity and the ecosystem approach in agriculture, forestry and fisheries. Proceedings, Rome, Italy, Food and Agriculture Organization of the United Nations (FAO), 2003, 12-13 October, 100-116.

[6]. K.T. Frank, B.Petrie, , J.S. Choi, and W.C. Leggett, Trophic cascades in a formerly cod-dominated ecosystem, Science, 2005, 308(5728), 1621-1623.

[7]. M.S. Islam, and S.U. Ahmad, By-catch mortality during collection of Penaeus monodon (FAB) post-larvae from the rivers of Khulna Bangladesh. Journal of the National Science Foundation of Sri Lanka, 2010, 29(3-4).

[8]. S. Kalpana, and R. N. Seth, Biotechnology in conservation of aquatic biodiversity. Flora and Fauna, $2001,7(2)$ 83-84.

[9]. I. G. Cowx, M. V. Knaap, L. I. Muhoozi, and A. Othina, Improving fishery catch statistics for Lake Victoria, Aquatic Ecosystem Health \& Management, 2003, 6(3), 299-310. 
[10]. E. O. Odada, D. O. Olago, and F. Bugenyi, Environmental assessment of the East African Rift Valley lakes, Aquatic-Sciences, Basel, Switzerland, 2003, 65(3), 254-271.

[11]. A. J. A. Raj, Conservation of threatened fish species by induced breeding techniques, Ph.D. Thesis, CARE, St. Xavier's College, Tirunelveli, India, 2002.

[12]. T. T. C. Edwards, and E. P. Éva, Protecting old fish through spatial management: is there a benefit for sustainable exploitation?, Journal of Applied Ecology, 2011, 48(4), 853-863.

[13]. K. M R. Kabir, R. K. Adhikary, M. B. Hossain, and M. H. Minar, Livelihood status of fishermen of the old Brahmaputra River, Bangladesh, World Applied Sciences Journal, 2012, 16(6), 869-873.

[14]. Allan, J. D., and S. F. Alexander, Biodiversity conservation in running waters, BioScience, 1993, 43(1), 32-43.

[15]. J. E. Williams, J. E. Johnson, D. A. Hendrickson, S. Contreras-Balderas, J. D. Williams, M. Navarro-Mendoza, D. E. McAllister, and J. E. Deacon, Fishes of North America endangered, threatened, or of special concern: 1989, Fisheries, 1989, 14(6), 2-20.

[16]. R. Abell, T. Michele, and L. Bernhard, Ecoregion conservation for freshwater systems with a focus on large rivers, World Wildlife Fund, Washington, DC, 2002.

[17]. S. Díaz, J. Fargione, F. C. Stuart, and D. Tilman, Biodiversity loss threatens human well-being, PLoS Biology, $2006,4(8), 277$. 